\title{
KARAKTERISTIK MINUMAN PROBIOTIK FERMENTASI Lactobacillus casei DARI SARI BUAH SALAK
}

\author{
Characteristic of Probiotic Drink Lactobacillus casei Fermentation from Snake Fruit Juice
}

Cahyaning Rini Utami

Prodi Ilmu dan Teknologi Pangan, Fakultas Pertanian, Universitas Yudharta Pasuruan

Email : cahyaningriniutami@gmail.com

\begin{abstract}
Snake Fruit is an indigenous fruit fromIndonesia with abundant presence. Snake fruit contains sucrose, fructose, and glucose utilized Lactic Acid Bacteria (LAB) during fermentation process so it can be made as a basic substance of probiotic drink. Utilization of snake fruit as a basic substance of probiotic drinks can increase the value of snake fruit. Making of probiotic drink is involving of Shirota strain Lactobacillus bacteria as a good probiotic agent. This study aim to determine the effect of addition of milk and fermentation time on the characteristics of probiotic drink fermentated L.casei made from snake fruit juice and also the best combination of the addition of milk and fermentation time. The method used in this study was Randomized Block Design (RBD)with two treatment.T he applied treatment was the addition of milk with variation of $5 \%$ and $10 \%(\mathrm{v} / \mathrm{v})$ with fermentation time of 2, 4, 6, 8 and 10 hours. The results of fermentation was analyzed by viscocity, $\mathrm{pH}$, sugar content, and organoleptic. All of data was analyzed by varian analysis ANOVA and continued by BNT test. The best selection using De Garmo methods. The result show that addition of milk and fermentation time have effect to characteristic of probiotic drink from snake fruit. Combination treatment percentage of milk addition by $10 \%(\mathrm{v} / \mathrm{v})$ with fermentation time 8 hours $(\mathrm{T} 2 \mathrm{~L} 4)$ is best treatment with characteristic: viscocity $12.90 \mathrm{cps}$; $\mathrm{pH}$ 4.82; sugar contain $7.43 \%$ and organoleptic value to taste, color, texture, and flavor were 5.49 (really like); 3.57(like); 3.65(like) and 3.66(like) respectively.
\end{abstract}

Keywords: Snake fruit, Probiotic Drink, Fermentation, L. casei strain Shirota

\begin{abstract}
ABSTRAK
Salak merupakan buah asli Indonesia yang keberadaanya melimpah. Salak mengandung sukrosa, fruktosa, dan glukosa yang dimanfaatkan bakteri asam laktat (BAL) selama proses fermentasi sehingga dapat dibuat sebagai bahan dasar minuman probiotik. Pemanfaatan salak sebagai bahan dasar minuman probiotik dapat meningkatkan nilai jual salak. Pembuatan minuman probiotik salak melibatkan bakteri Lactobacillus casei strain Shirota sebagai agen probiotik yang baik. Penelitian ini bertujuan untuk mengetahui pengaruh penambahan susu dan waktu fermentasi terhadap karakteristik minuman probiotik fermentasi L.casei dari sari buah salak serta kombinasi terbaik penambahan susu dan waktu fermentasi. Metode yang digunakan dalam penelitian adalah rancangan acak kelompok (RAK) dengan 2 perlakuan. Perlakuan yang diterapkan adalah penambahan susu dengan variasi $5 \%$ dan $10 \%(\mathrm{v} / \mathrm{v})$ dengan waktu fermentasi 2, 4, 6, 8 dan 10 jam. Hasil fermentasi diuji viskositas, $\mathrm{pH}$, kadar gula total dan organoleptik. Seluruh data dianalisa menggunakan analisis varian (ANOVA) yang dilanjutkan dengan uji BNT. Pemilihan terbaik dengan metode De Garmo. Hasil penelitian menunjukkan penambahan susu dan waktu fermentasi berpengaruh terhadap karakteristik minuman probiotik salak. Kombinasi perlakuan persentase penambahan susu sebesar $10 \%(\mathrm{v} / \mathrm{v})$ dengan waktu fermentasi 8 jam (T2L4) merupakan hasil terbaik dengan karakteristik: viskositas 12,90 cps; pH 4,82; kadar gula 7,43\% dan nilai organoleptik terhadap rasa, warna, tekstur, dan aroma berturut-turut sebesar 5,49 (sangat suka); 3,57(suka) ; 3,65(suka); dan 3,66(suka).
\end{abstract}

Kata Kunci: Salak, Minuman probiotik, Fermentasi, L. casei strain Shirota 


\section{PENDAHULUAN}

Salak merupakan produk pertanian Indonesia yang tersebar hampir di seluruh kepulauan Nusantara dimana terdapat beberapa varietas buah salak seperti salak condet, salak pondoh, salak gula pasir, salak enrekang, salak nangka, salak Bali, salak kersikan, salak swaru, salak ambrawa, salak padang sidempuan, salak nglumut, salak mawar dan salak Bangkok (Anonim, 2010). Diantara berbagai jenis salak tersebut, salak kersikan masih kurang komersial dibandingkan salak pondoh dan gula batu atau Bali yang ditetapkan pemerintah sebagai salak dengan nilai komersial yang tinggi. Salak kersikan merupakan salah satu komoditas unggulan dan keberadaanya sangat melimpah di Desa Kersikan, Pasuruan, Jawa Timur. Sangat disayangkan apabila nilai komersial salak kersikan ini sangatlah rendah. Produksi salak kersikan yang melimpah pada saat terjadinya panen raya menimbulkan permasalahan terhadap petani. Tidak sedikit petani salak yang mengalami kerugian karena menjual dengan harga rendah. Selain itu, permasalahan lain yang timbul, seperti banyak salak yang tidak terjual, menjadi busuk dan mudah rusak (perishability). Salah satu cara mengatasi masalah tersebut dengan mengolah salak menjadi minuman probiotik sehingga dapat menambah nilai jual salak dan meningkatkan daya tahannya.

Minuman probiotik adalah minuman yang mengandung bakteri seperti bakteri asam laktat (BAL) yang menguntungkan bagi saluran pencernaan karena dapat meningkatkan keseimbangan mikroflora usus dan mampu bertahan hidup dalam keasaman lambung sehingga dapat menempati usus dalam kuantitas yang cukup besar (Herlina dan Nuraeni, 2014). Minuman probiotik yang sudah dikenal masyarakat selama ini diproduksi dari hasil fermentasi susu antara lain yogurt, susu asidofilus, bulgarian milk, kefir, dahi dari India, hamao dari Asia Tengah, yakult, dan lain-lain (Pereira, 2018). Minuman probiotik tersebut harganya relatif lebih mahal sehingga perlu digunakan bahan alternatif lain salah satunya dengan bahan dasar buah salak untuk memperoleh minuman probiotik yang lebih terjangkau bagi masyarakat. Harapannya dapat meningkatkan nilai komersial dari salak daerah kersikan. Salak kersikan memiliki rasa khas yang manis dan berair. Salak mengandung sukrosa, fruktosa, dan glukosa. Gula yang terkandung dalam salak tersebut akan dimanfaatkan oleh bakteri asam laktat sebagai sumber karbon selama fermentasi berlangsung sehingga terbentuk asam laktat yang merupakan hasil metabolit. Kandungan gula sederhana pada salak kersikan yang tertinggi yaitu sukrosa sebesar 10,81\% (Hadiati, 2012). Kandungan sukrosa yang tinggi dalam salak juga akan memberikan rasa manis pada minuman probiotik. Penelitian yang sudah dilakukan oleh Setianto (2014) adalah membuat minuman yoghurt menggunakan salak pondoh sebagai bahan dasar minuman probiotik. Penelitian mengenai pembuatan minuman probiotik dari salak kersikan masih belum ada.

Produk probiotik dari minuman salak merupakan salah satu aplikasi bioteknologi yang memanfaatkan bakteri asam laktat sebagai agen probiotik. Pemilihan bakteri asam laktat menjadi faktor penting dalam keberhasilan pembuatan minuman probiotik dari salak. Peranan bakteri asam laktat sebagai agen probiotik sangat ditentukan oleh sifatnya yaitu tetap dalam keadaan hidup sejak dikonsumsi hingga mencapai usus manusia. Tidak semua bakteri asam laktat mempunyai sifat demikian. Pada umumnya bakteri asam laktat yang berasal dari saluran pencernaan manusia seperti Lactobacillus dan Bifidobacterium dapat berperan sebagai probiotik yang baik, sedangkan Streptococcus dan Lactococcus yang merupakan kultur fermentasi produk susu tidak dapat mencapai usus manusia dalam keadaan hidup (Ahmed et al. 2010). Syarat utama strain yang dapat digunakan sebagai agen probiotik adalah memiliki resistensi terhadap asam dan empedu sehingga dapat mencapai intestin dan memiliki kemampuan menempel pada 
mukosa intestin (Allen et al. 2011). Syarat lain yang perlu dimiliki oleh bakteri probiotik adalah kemampuannya menghasilkan substansi antimikrobia sehingga mampu menekan pertumbuhan bakteri patogen, tumbuh baik secara in vitro, memiliki stabilitas yang tinggi dan aman bagi manusia. Dari berbagai persyaratan diatas Lactobacillus casei strain Shirota masuk dalam kriteria diatas (Sunaryanto, 2014) dan berpotensi sebagai agen probiotik yang baik. Pembuatan minuman probiotik dari salak pada penelitian ini memanfaatkan bakteri asam laktat yaitu Lactobacillus casei strain Shirota yang diharapkan mampu memenuhi kebutuhan probiotik hidup sekaligus menjadi sumber elektrolit dan bermanfaat bagi kesehatan.

Penelitian ini melibatkan dua faktor yang dapat menentukan kualitas produk yaitu konsentrasi susu dan lama fermentasi. Penggunaan susu pada produk minuman probiotik ini diperlukan pada proses pengolahan minuman probiotik dengan maksud meningkatkan nilai gizi pada produk. Susu menjadi sumber karbon tambahan untuk mikroorganisme pada saat fermentasi berlangsung. Susu yang digunakan adalah susu UHT dengan tujuan memudahkan pembuatan minuman fermentasi dari salak tanpa melalui proses sterilisasi susu terlebih dulu. Sementara lama fermentasi akan menentukan kemampuan bakteri memecah nutrisi di dalam medium secara optimal (Retnowati, 2013). Penambahan konsentrasi susu UHT dan lama fermentasi yang berbeda akan mempengaruhi karakter meliputi: viskositas, $\mathrm{pH}$, kadar gula dan organoleptik dari produk yang dihasilkan.

\section{METODE PELAKSANAAN}

\section{Bahan}

Bahan yang digunakan pada penelitian ini adalah salak varietas lokal yang didapat dari perkebunan salak di Desa Kersikan Kecamatan Gondang Wetan Kabupaten Pasuruan Jawa Timur, kultur biakan L.casei strain Shirota dari minuman Yakult, susu
Ultra High Temperature (UHT) fullcream, sukrosa dan akuades.

Alat

Alat yang digunakan dalam penelitian ini:(1) peralatan gelas berupa botol kaca 100 $\mathrm{mL}$; beaker glass $1000 \mathrm{~mL}$; corong kaca; pengaduk; termometer suhu ruang; tabung reaksi; pipet tetes; pipet volum $10 \mathrm{~mL}$ (2) alat penunjang lain seperti kompor, pisau, neraca analitik, blender, autoklaf, pHmeter digital TOA DKK HM-3OP, densitymeter Mettler Toledo DM40, viskometer Brookfield DV2T, kertas saring Whatman no.92, aluminium foil dan inkubator.

\section{Pembuatan Sari Buah Salak}

Buah salak yang dipilih adalah buah salak yang cukup matang dan dalam kondisi baik serta layak dikonsumsi. Sebanyak 900 g salak disortir dengan tingkat kematangan yang sama, dikupas kulitnya, dibuang bijinya, dipotong kecil-kecil dan dicuci bersih dengan air. Buah salak yang sudah dipotong kecil-kecil ditambahkan air dengan perbandingan air dan salak 4:1. Ditambahkan gula 4\% (b/v) dan dihaluskan menggunakan blender sampai menjadi jus. Selanjutnya disaring menggunakan kertas saring sampai mendapatkan sari buah (ekstrak) salak kemudian dituang ke dalam beaker glass yang steril dan ditutup alumunium foil. Sari salak diautoklaf suhu $121^{\circ} \mathrm{C}, 1$ atm selama 15 menit dan didiamkan sampai dingin.

\section{Fermentasi Minuman Salak dengan L.casei}

Sari buah salak dituang kedalam botol kaca $100 \mathrm{~mL}$ yang sudah steril. Masingmasing sari buah salak ditambahkan 5\% (v/v) inokulum L. casei dan susu UHT dengan variasi penambahan susu 5\% (v/v) dan $10 \%(\mathrm{v} / \mathrm{v})$. Pemilihan jumlah inokulum L.casei $5 \%(\mathrm{v} / \mathrm{v})$ didasarkan pada penelitian Yanuar (2015). Selanjutnya minuman yang sudah diinokulasi tersebut diinkubasi pada suhu $37^{\circ} \mathrm{C}$ dengan variasi waktu fermentasi 2, 4, 6, 8 dan 10 jam. Suhu optimum dari 
L.casei pada minuman fermentasi adalah pada suhu $37^{\circ} \mathrm{C}$ (Colomboa et al., 2014).

\section{Karakterisasi Minuman Probiotik Sari Buah Salak}

Sampel minuman salak fermentasi dikarakterisasi untuk mengetahui sifat kimia yang paling baik dari produk fermenasi dengan uji $\mathrm{pH}$, kadar gula total dan nilai viskositas. Uji $\mathrm{pH}$ dilakukan menggunakan pHmeter untuk menentukan nilai derajat keasaman (AOAC, 2012). Nilai viskositas diuji dengan viskometer (Daubert and Farkas, 2013) sedangkan kadar gula total ditentukan dengan metode Brix. Karakteristik kimia yang dihasilkan akan disinkronkan dengan hasil uji organoleptik. Uji organoleptik meliputi rasa, tekstur, warna dan aroma dilakukan pada 10 orang panelis agak terlatih.

\section{Analisa Data dan Statistik}

Penelitian ini menggunakan Rancangan Acak Kelompok (RAK) dengan dua faktor. Faktor pertama adalah presentase penambahan susu UHT pada minuman fermentasi salak dengan konsentrasi terdiri dari 2 perlakuan: $\mathrm{T} 1=5 \%$ susu dan $\mathrm{T} 2=10 \%$ susu. Faktor kedua: lama fermentasi terdiri dari 5 perlakuan, yaitu $\mathrm{L} 1=2 \mathrm{jam}, \mathrm{L} 2=4$ jam, L3= 6 jam, L5= 8 jam dan L5= 10 jam. Dari dua faktor tersebut terdapat 8 kali percobaan. Masing-masing percobaan dulang sebanyak dua kali sehingga total ada 16 kali percobaan. Data yang dihasilkan dilakukan uji analisis ragam ANOVA apabila ditemukan pengaruh terhadap salah satu variabel maka dilanjutkan dengan uji BNT pada taraf 5\%. Uji Organoleptik menggunakan metode Hedonic Scalling Scoring dan analisis perlakuan terbaik menggunakan metode De Garmo.

\section{HASIL DAN PEMBAHASAN}

\section{Viskositas}

Berdasarkan hasil uji viskositas diperoleh rata-rata nilai viskositas berkisar 12,85-12,91 cps. Nilai viskositas yang dihasilkan pada minuman probiotik salak sama dengan karakteristik yoghurt bahwa produk fermentasi seperti yoghurt mempunyai viskositas antara 8,28-13,00 cps (Winarno dan Fernandez, 2007). Analisis ragam menunjukkan bahwa perlakuan kombinasi waktu fermentasi dan penambahan susu UHT tidak berpengaruh nyata terhadap nilai viskositas dari minuman probiotik salak. Rata-rata nilai viskositas setiap perlakuan ditampilkan Gambar 1 .

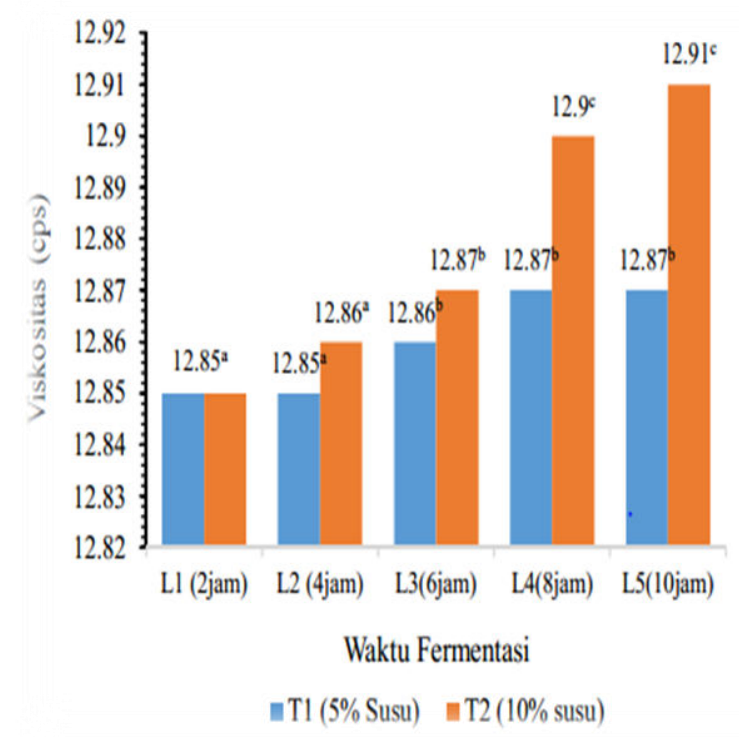

Gambar 1. Viskositas rata-rata minuman probiotik dari salak yang difermentasi L.casei

Gambar 1 menunjukkan bahwa nilai viskositas naik seiring dengan lamanya waktu fermentasi baik pada penambahan susu $5 \%$ maupun $10 \%$. Waktu fermentasi menyebabkan peningkatan jumlah asam laktat yang terbentuk oleh bakteri asam laktat sehingga kasein dalam susu mengalami koagulasi membentuk gel. Terbentuknya gel menyebabkan tekstur semi padat sehingga semakin lama viskositas naik, hal ini sejalan dengan penelitian Diantoro, Rohman, Budiarti, Palupi (2015). Nilai viskositas dari penambahan susu $5 \%$ dan $10 \%$ sama pada waktu fermentasi 2 jam yaitu sebesar 12,85 cps. Hal ini dimungkinkan karena proses fermentasi masih belum terjadi, bakteri asam laktat masih dalam tahap adaptasi, tetapi nilai 
viskositasnya sudah tinggi. Viskositas yang tinggi disebabkan salak mengandung pektin yang dapat membentuk gel sehingga minuman probiotik menjadi kental. Hal ini sesuai dengan penelitian Rismawati (2015) bahwa pektin dalam salak mempunyai sifat dapat larut dalam air tetapi apabila dicampur dengan gula dan asam akan membentuk gel, karena pektin adalah koloid yang reversible.

Perlakuan penambahan susu berpengaruh terhadap nilai viskositas. Persentase susu yang lebih besar menyebabkan viskositas semakin tinggi. Hal ini disebabkan semakin tinggi kadar protein susu dalam produk fermentasi maka kekentalan (viskositas) produk semakin meningkat (Rahmawati, 2016). Nilai viskositas paling tinggi dihasilkan perlakuan kombinasi T2L5 yaitu pada $10 \%$ susu dengan waktu fermentasi 10 jam, nilai ini tidak jauh berbeda dengan perlakuan T2L4 (10\% susu dengan 8 jam fermentasi) yaitu 13,9 cps.

\section{pH}

Hasil analisis menunjukkan rata-rata nilai pH berkisar antara 5,1-4,8. Berdasarkan analisis ragam perlakuan waktu fermentasi dan penambahan susu berpengaruh nyata terhadap nilai $\mathrm{pH}$. Perubahan $\mathrm{pH}$ pada setiap perlakuan disajikan dalam Gambar 2.

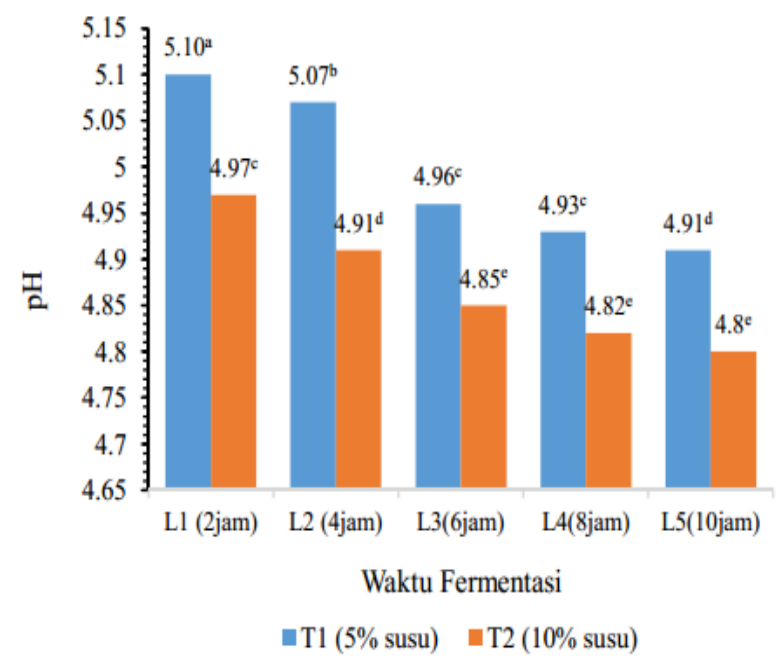

Gambar 2. Nilai $\mathrm{pH}$ rata-rata minuman probiotik dari salak yang difermentasi L.casei
Gambar 2 menunjukkan terjadi penurunan $\mathrm{pH}$ seiring bertambahnya jumlah susu dan lama fermentasi. Penurunan $\mathrm{pH}$ merupakan salah satu akibat dari proses fermentasi yang terjadi karena adanya akumulasi asam laktat sebagai produk utama dari bakteri homofermentatif (Fanworth, 2005). Semakin tinggi penambahan susu, kebutuhan nutrisi bagi pertumbuhan bakteri juga semakin terpenuhi sehingga bakteri yang tumbuh lebih banyak dan bakteri tersebut akan merombak laktosa yang ada dalam susu menjadi asam laktat (Triyono, 2010). Semakin lama waktu fermentasi, semakin banyak asam-asam organik yang terakumulasi akan meningkatkan derajat keasaman produk (Pranayanti, 2015).

Nilai $\mathrm{pH}$ terendah ditunjukkan oleh perlakuan T2 (10\% susu) dengan waktu fermentasi 8 dan 10 jam yitu sebesar 4,82 dan 4,80. Selisih pH yang tidak jauh berbeda tersebut sejalan dengan nilai viskositasnya yang tidak jauh berbeda pada data sebelumnya. Dapat dikatakan perlakuan T2L4 dan T2L5 tidak cukup signifikan berpengaruh terhadap nilai $\mathrm{pH}$ dan viskositas. Perbedaan kedua perlakuan dapat dilihat berdasarkan hasil organoleptik dan kadar gula total.

\section{Kadar Gula Total}

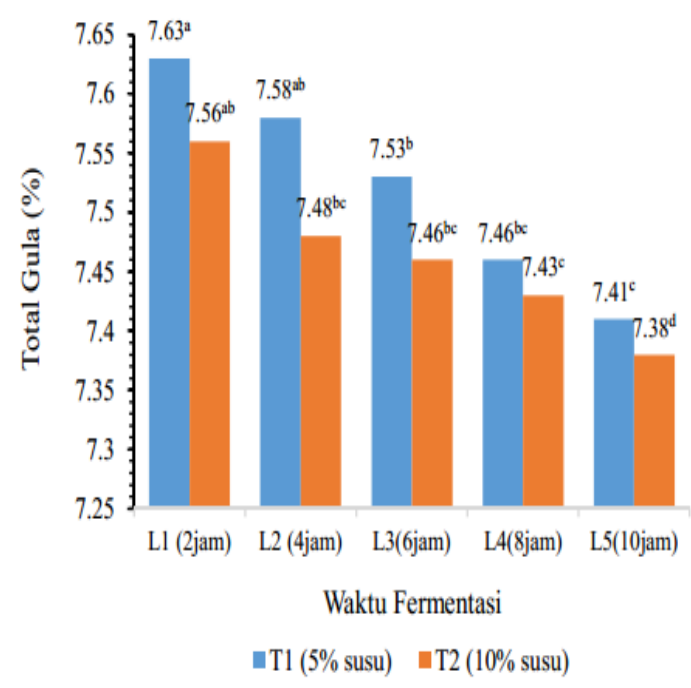

Gambar 3. Total Gula rata-rata minuman probiotik dari salak yang difermentasi L.casei 
Berdasarkan hasil uji nilai rata-rata kadar gula total minuman probiotik salak berkisar antara 7,38-7,63\%. Analisis ragam menunjukkan perlakuan kombinasi waktu fermentasi dan penambahan susu berpengaruh sangat nyata terhadap kadar gula total. Terjadi penurunan kadar gula total selama proses fermentasi berlangsung terhadap dua perlakuan. Nilai kadar gula total setiap perlakuan disajikan pada Gambar 3.

Gambar 3 menunjukkan semakin lama waktu fermentasi, semakin turun kadar gula totalnya. Pada proses fermentasi terjadi metabolisme bakteri yang menggunakan glukosa sebagai nutrisi pertumbuhannya, kemudian glukosa tersebut diubah menjadi asam laktat. Kadar total gula mengalami penurunan karena semakin lama waktu fermentasi, maka jumlah bakteri asam laktat meningkatdan mempengaruhi seberapa besar total gula yang dirombak menjadi asam laktat sebagai metabolit bakteri asam laktat. Hal tersebut sejalan dengan penelitian Retnowati (2014) menunjukkan bahwa meningkatnya asam laktat menunjukkan bahwa total gula semakin menurun. Kadar gula total terendah dihasilkan oleh perlakuan T2L5 (10\% susu dengan 10 jam fermentasi) dengan kadar gula total sebesar 7,38\%. Nilai tersebut berbeda cukup signifikan dengan perlakuan T2L4 (10\% susu dengan 8 jam fermentasi). Artinya perlakuan waktu fermentasi berpengaruh terhadap kadar gula total minuman probiotik salak. Hasil dari uji karakteristik kimia ini selanjutnya akan dibandingkan dengan organoleptik untuk menghasilkan perlakuan yang terbaik.

\section{Organoleptik Produk Minuman Probiotik Salak}

Uji Organoleptik dilakukan dengan tujuan untuk mengetahui tingkat kesukaan dan penerimaan panelis terhadap produk. Terdapat 10 sampel produk yang diujikan adalah minuman probiotik salak dengan penambahan susu 5\%, dan $10 \%$ serta lama fermentasi 2, 4, 6, 8 dan 10 jam. Minuman probiotik ini memiliki citarasa khusus yaitu rasa asam dengan perpaduan rasa dari sari buah salak. Uji organoleptik meliputi uji Rasa, Aroma, Warna dan tekstur. Uji ini dilakukan dengan menggunakan metode Hedonic Scalling Scoring. Skala hedonik ditransformasi ke dalam skala numerik menurut tingkat kesukaan panelis mulai dari angka terkecil hingga angka terbesar (1-7= tidak suka sampai sangat suka).

\section{Rasa}

Tingkat kesukaan panelis terhadap rasa minuman probiotik salak dapat dilihat Tabel 1. Berdasarkan hasil uji, rata-rata tingkat kesukaan panelis terhadap rasa minuman probiotik salak berkisar antara 4,01-5,49 (suka-sangat suka). Skor rasa tertinggi dihasilkan pada perlakuan T2L4 yaitu penambahan $10 \%$ susu dengan 8 jam fermentasi sebesar 5,49 (sangat suka). Menurut catatan panelis pada perlakuan penambahan susu10\% minuman probiotik yang dihasilkan memiliki cita rasa yoghurt (sedikit asam) sedangkan pada penambahan $5 \%$ susu rasanya masih dominan buah salak. Selama fermentasi terjadi pembentukan asam laktat yang secara tidak langsung akan berdampak pada penurunan $\mathrm{pH}$ dan akan memberikan cita rasa khas produk fermentasi (Widagdha, 2014).

\section{Warna}

Tingkat kesukaan panelis terhadap warna minuman probiotik salak dapat dilihat Tabel 1. Dari Tabel 1 didapatkan rata-rata tingkat kesukaan panelis terhadap warna minuman probiotik salak berkisar antara 3,30-3,78 (netral-suka). Rata-rata skor warna terendah dihasilkan pada perlakuan T1L1 yaitu penambahan 5\% susu dengan 2 jam fermentasi. Skor tertinggi dihasilkan oleh perlakuan T2L5 yaitu penambahan $10 \%$ susu dengan 10 jam fermentasi sebesar 3,78 (suka). Panelis lebih menyukai warna minuman probiotik salak dengan penambahan susu yang tinggi dengan waktu fermentasi lama. Hal ini diduga karena dengan penambahan susu yang tinggi menyebabkan warna minuman probiotik 
berubah dari bahan baku awal. Panelis lebih cenderung menyukai minuman probiotik yang berwarna kuning tua daripada yang berwarna kuning pucat. Warna dipengaruhi oleh komponen penyusun dalam bahan dan proses pembuatan produk. Perbedaan penambahan jumlah susu memberikan pengaruh terhadap warna setelah fermentasi melalui pembentukan metabolit sehingga mengakibatkan warna akhir produk berbedabeda (Winarno, 2007).

\section{Tekstur}

Tingkat kesukaan panelis terhadap tekstur minuman probiotik salak dapat dilihat Tabel 1. Rata-rata tingkat kesukaan panelis terhadap tekstur berkisar antara 2,45-3,66 (sedikit suka- suka). Skor tekstur tertinggi dihasilkan pada perlakuan T2L5 (10\% susu dengan 10 jam fermentasi) dan skor terendah dihasilkan pada perlakuan T1L1 (5\% susu dengan 2 jam fermentasi). Panelis lebih menyukai tekstur minuman probiotik salak yang kental yaitu pada perlakuan T2L5 dan T2L4 sebesar 3,65 (suka) dan 3,66 (suka). Hal ini sejalan dengan hasil uji viskositas bahwa perlakuan T2L4 dengan T2L4 hasil viskositasnya tidak jauh berbeda. Kekentalan produk terbentuk dari metabolit-metabolit hasil fermentasi Lactobacillus casei strain Shirota selama fermentasi (Sunaryanto, 2014).

\section{Aroma}

Tingkat kesukaan panelis terhadap aroma minuman probiotik salak dapat dilihat Tabel 1. Dari Tabel 1 menunjukkan rata-rata tingkat kesukaan terhadap aroma berkisar 3,12-3,66 (netral-suka). Skor aroma tertinggi dihasilkan oleh perlakuan T2L4, penambahan susu $10 \%$ dengan lama fermentasi 8 jam sebesar 3,66(suka). Menurut panelis aroma yang dihasilkan produk beraroma buah umumnya, semakin lama proses fermentasi aroma yang dihasilkan memiliki cita rasa yoghurt. Pada perlakuan T2L4 memiliki aroma khas yoghurt rasa buah salak sehingga lebih disukai. Aroma khas produk probiotik diperoleh dari asam laktat sebagai hasil metabolisme bakteri yang dapat memberikan ketajaman rasa. Menurut Pereira (2018) selain berperan dalam pembentukan gel, asam laktat dapat memberikan ketajaman rasa dan menentukan aroma khas dari minuman probiotik.

Tabel 1. Hasil Uji Organoleptik Minuman Probiotik dari Salak difermentasi L.casei

\begin{tabular}{|c|c|c|c|c|c|}
\hline \multirow{2}{*}{$\begin{array}{c}\text { Penambahan } \\
\text { Susu }\end{array}$} & \multirow[t]{2}{*}{ Waktu Fermentasi } & \multicolumn{4}{|c|}{ Skor } \\
\hline & & Rasa & Warna & Tekstur & Aroma \\
\hline \multirow{5}{*}{$\mathrm{T} 1(5 \%)$} & L1(2 jam) & $4,01^{\mathrm{a}}$ & $3,30^{\mathrm{a}}$ & $2,45^{\mathrm{a}}$ & $3,12^{\mathrm{a}}$ \\
\hline & $\mathrm{L} 2(4$ jam $)$ & $4,23^{\mathrm{ab}}$ & $3,34^{\mathrm{ab}}$ & $2,49^{\mathrm{a}}$ & $3,28^{\mathrm{ab}}$ \\
\hline & L3(6 jam) & $4,45^{\mathrm{b}}$ & $3,45^{\mathrm{c}}$ & $2,59^{\mathrm{b}}$ & $3,31^{\mathrm{b}}$ \\
\hline & $\mathrm{L} 4(8$ jam $)$ & $4,48^{\mathrm{b}}$ & $3,54^{\mathrm{cd}}$ & $2,63^{b c}$ & $3,29^{\mathrm{ab}}$ \\
\hline & L5(10 jam $)$ & $4,45^{\mathrm{b}}$ & $3,61^{\mathrm{d}}$ & $2,78^{\mathrm{c}}$ & $3,33^{\mathrm{b}}$ \\
\hline \multirow{5}{*}{$\mathrm{T} 2(10 \%)$} & L1(2 jam) & $4,22^{\mathrm{ab}}$ & $3,35^{\mathrm{ab}}$ & $2,59^{b}$ & $3,36^{\mathrm{b}}$ \\
\hline & $\mathrm{L} 2(4$ jam $)$ & $4,76^{\mathrm{bc}}$ & $3,39^{\mathrm{b}}$ & $3,12^{\mathrm{cd}}$ & $3,15^{\mathrm{a}}$ \\
\hline & L3(6 jam) & $5,16^{\mathrm{c}}$ & $3,49^{\mathrm{c}}$ & $3,34^{\mathrm{d}}$ & $3,31^{\mathrm{b}}$ \\
\hline & $\mathrm{L} 4(8$ jam $)$ & $5,49^{\mathrm{d}}$ & $3,57^{\mathrm{cd}}$ & $3,65^{\mathrm{e}}$ & $3,66^{\mathrm{c}}$ \\
\hline & L5(10 jam) & $5,12^{c}$ & $3,78^{\mathrm{e}}$ & $3,66^{\mathrm{e}}$ & $3,30^{\mathrm{b}}$ \\
\hline
\end{tabular}




\section{KESIMPULAN DAN SARAN}

\section{Kesimpulan}

Berdasarkan hasil perlakuan penambahan susu dan waktu fermentasi berpengaruh terhadap karakteristik minuman probiotik salak yang difermentasi menggunakan L.casei strain Shirota. Perlakuan terbaik ditentukan dengan metode de Garmo dihasilkan pada kombinasi perlakuan T2L4 yaitu penambahan susu sebanyak $10 \%$ dengan waktu fermentasi 8 jam. Karakteristik kimia perlakuan T2L4 adalah sebagai berikut: viskositas sebesar 12,90 cps; pH sebesar 4,82 dan kadar total gula sebesar $7,43 \%$. Sifat organoleptik yang dihasilkan perlakuan T2L4 meliputi rasa, warna, tekstur dan aroma berturut-turut sebesar 5,49(sangat suka); 3,57(suka); 3,65 (suka) dan 3,66 (suka).

\section{Saran}

1. Penelitian selanjutnya diharapkan dapat meneliti jumlah inokulum L.casei strain Shirota yang diberikan selama proses fermentasi untuk melihat jumlah pemberian inokulum dengan dosis yang tepat.

2. Penelitian selanjutnya diharapkan dapat meneliti variasi substrat salak kersikan untuk mengetahui kebutuhan salak yang dibutuhkan menjadi minuman probiotik.

\section{DAFTAR PUSTAKA}

[AOAC] Association of Official Analitycal Chemist. (2012). Official Methods of Analisys Chemist., $19^{\text {th }}$ edition. Inc., Washington.

Ahmed Z, Y Wang, Q Cheng, M Imran. (2010). Lactobacillus acidophillus Bacteriocin, from Production to Their Application: An Overview. Afr. J.Biotech. 9(20):2843-2850.

Allen, S.J., Martinez E.G., Gregorio, G.V., Dans, L.V. (2011). Probiotics for Treating Acute Infectious Diarrhoea. John Wiley \& Sons Ltd. UK.
Anonim. (2010). Kawasan Pengembangan Salak. Direktorat Budidaya Tanaman Buah, Direktorat Jenderal Hortikultura, Departemen Pertanian.

Colomboa, et al. (2014). Development of an Alternative Culture Medium for the Selective Enumeration of Lactobacillus casei in Fermented Milk. Food Microbiology. 39:89-95.

Daubert, C.R., Farkas, B.E. (2013). Food Analysis Laboratory: Viscocity Measurement Using a Brookfield Viscometer. 139-142. Springer USA.

Diantoro, A., Rohman, M., Budiarti, R., Palupi H.T. (2015). Pengaruh Penambahan Ekstrak Daun kelor (moringa oleifera l.) Terhadap Kualitas Yoghurt. J. Tek. Pangan. 6(2):59-66.

Farnworth, E.D.R. (2005). Handbook of Fermented Functional Foods. CRC Press LLC. Florida

Hadiati, S., T. Budiyanti, A. Soemargono, and A.Susiloadi. (2012). Characterization of Fruit on Several Salak Varieties and Their Hybrids. Agrivita. 34(2): 188-193.

Herlina, E. dan Nuraeni, F. (2014). Pengembangan Produk Pangan Fungsional Berbasis Ubi Kayu (Manihot esculenta) dalam Menunjang Ketahanan Pangan. J. Sains Dasar. 3 (2):142-148.

Pereira, A.L., Rodrigues, S. (2018). Fruit Juices Extraction, Composition, Quality and Analysis: Turning Fruit Juice into Probiotic Beverages. Academic Press. 279-287.

Rahmawati, I. S., Suntornsuk, W. (2016). Effects of Fermentation and Storage on Bioactive Activities in Milks and Yoghurts. Procedia Chemistry. 18: 53 -62 .

Retnowati, P.A. (2013). Pembuatan Minuman Probiotik Sari Buah Kurma (Phoenix dactilyfera L.) dengan Isolat Lactobacillus casei dan Lactobacillus plantarum (kajian proporsi buah kurma:air dan lama fermentasi). 
Skripsi. Universitas Brawijaya. Malang.

Rismawati, F. (2015). Pengaruh Perbandingan Air Dengan Buah Salak Dan Konsentrasi Penstabil Terhadap Karakteristik Minuman Sari Buah Salak Bongkok (Salacca Edulis, Reinw). Tesis. Universitas Pasundan. Bandung.

Setianto, Y.C., Pramono, Y.K., Mulyani, S. (2014). Nilai pH, Viskositas, dan Tekstur Yoghurt Drink dengan Penambahan Ekstrak Salak Pondoh (Salacca zalacca). J. Aplikasi Tek. Pangan. 3 (3):110-113.

Sunaryanto, R., Martius, E., Marwoto, B. (2014). Uji Kemampuan Lactobacillus casei Sebagai Agensia Probiotik. J. Biotek \& Biosains Indonesia. 1(1):915.
Triyono, A. (2010). Mempelajari Pengaruh Maltodekstrin dan Susu terhadap Karakteristik Yoghurt Kacang Hijau (Phaseolus radiatus L.). Seminar Rekayasa Kimia dan Proses. Proceeding: 1411-4216.

Widagdha, S. (2014). Pengaruh Penambahan Sari Anggur (Vitis vinifera L.) dan Perbedaan Lama Fermentasi terhadap Karakteristik Fisik dan Kimia Yoghurt. Skripsi. Universitas Brawijaya. Malang.

Winarno, F. G. dan Fernandez, I. E. (2007). Susu dan Produk Fermentasinya. Mbrio Press, Bogor.

Yanuar, S.E., Sutrisno, A. (2015). Minuman Probiotik dari Air Kelapa Muda dengan Starter Bakteri Asam Laktat Lactobacillus casei. J. Pangan dan Agroindustri. 3(3): 909-917. 